Tadeusz Józef KĘSON

Szkoła Gtówna Stużby Pożarniczej w Warszawie ${ }^{1}$

Instytut Bezpieczeństwa Wewnętrznego

tkeson@sgsp.edu.pl

ORCID 0000-0002-7047-7811

https://doi.org/10.34739/dsd.2020.01.03

\title{
PLANOWANIE OBRONNE I CYWILNE \\ W POLSCE - UWARUNKOWANIA PRAWNE \\ A PROCES REALIZACJI
}

\begin{abstract}
ABSTRAKT: Uregulowane prawnie procesy planowania obronnego i cywilnego powinny w skuteczny sposób przygotowywać struktury państwa do funkcjonowania zarówno w czasie pokoju i zagrożeń zewnętrznych, jak i w maksymalnie skuteczny sposób umożliwiać reagowanie w sytuacjach kryzysowych. Wskazanie podmiotów uczestniczących w tych procesach i zawartości poszczególnych planów i programów niewątpliwie wyeliminowało wiele problemów organizacyjnych i decyzyjnych. Analiza procesów mających wpływ na przebieg planowania obronnego wykazała, że bezpieczeństwo państwa nie zawsze jest zasadniczą kwestią dla polityków, a troska o niezakłócone funkcjonowanie procesu planowania staje się nieistotna. Nieprzestrzegane są przez podmioty odgrywające zasadniczą rolę $\mathrm{w}$ procesie planowania obronnego terminy i postanowienia aktów prawnych wpływających na cykl planowania strategicznego w państwie.
\end{abstract}

SŁOWA KLUCzOWE: planowanie obronne, planowanie cywilne, cykl planowania strategicznego

\section{DEFENCE AND CIVIL PLANNING IN POLAND - LEGAL CONDITIONS AND IMPLEMENTATION PROCESS}

\begin{abstract}
Legally regulated processes of defence and civil planning should effectively prepare the structures of the state to function both in times of peace and external threats, as well as to respond to crisis situations in the most efficient way. Indication of entities participating in these processes and the content of individual plans and programmes undoubtedly eliminated many organizational and decision-making problems. Analysis of processes affecting the course of defence planning has shown that state security is not always a fundamental issue for politicians, and care for the undisrupted functioning of the planning process becomes irrelevant. The deadlines and provisions of legal acts influencing the cycle of strategic planning in the state are not respected by entities playing an essential role in the process of defence planning.
\end{abstract}

KEYWORDS: defence planning, civil planning, strategic planning cycle

\footnotetext{
${ }^{1}$ The Main School of Fire Service in Warsaw; Poland.
} 


\section{WPROWADZENIE}

Zapewnianie bezpieczeństwa państwa i obywateli, stosownie do postanowień art. 5 Konstytucji RP, wymaga skutecznego przygotowania struktur państwa do działania nie tylko w różnych dynamicznie zmieniających się warunkach czy też sytuacjach kryzysowych, lecz także w poszczególnych stanach gotowości obronnej państwa oraz konstytucyjnych stanach nadzwyczajnych. Wymusza to zapewnienie, z formalno-prawnego punktu widzenia, skutecznego i zorganizowanego systemu przygotowania się do aktywności struktur administracyjnych na każdym szczeblu podziału administracyjnego państwa. Jednocześnie nie wolno zapominać, że zapewnianie bezpieczeństwa to nie tylko powinność struktur państwa i administracji rządowej i samorządowej na każdym szczeblu podziału administracyjnego kraju - realizujących zadania obronne i zarządzania kryzysowego, lecz także przedsiębiorców podlegających militaryzacji oraz uczestniczących $\mathrm{w}$ procesie zabezpieczenia funkcjonowania infrastruktury krytycznej czy też istotnej dla funkcjonowania społeczności lokalnej.

Jakkolwiek procesy planowania obronnego i cywilnego oraz zadania poszczególnych organów zostały uregulowane zarówno w ustawach, jak i aktach wykonawczych, w ostatnich latach dają się zauważyć poważne rozbieżności między postanowieniami aktów prawych, a procesem realizacji planowania obronnego w państwie.

Celami artykułu są:

- przedstawienie prawnych uwarunkowań procesów planowania obronnego i cywilnego oraz ogólnej zawartości planów opracowywanych w tych procesach;

- omówienie cyklu planowania strategicznego;

- wskazanie rozbieżności między postanowieniami prawa w zakresie planowania obronnego a rzeczywistym procesem realizacji przedsięwzięć w latach 2015-2019.

Dla tak sformułowanych celów określono następujące problemy badawcze:

- Jakie podmioty uczestniczą $\mathrm{w}$ procesach planowania obronnego i cywilnego oraz jakie powinności nakładają na nie akty prawne regulujące te procesy w Polsce?

- Jak przebiega cykl planowania strategicznego oraz jakie rozbieżności wystąpiły między postanowieniami prawa $\mathrm{w}$ zakresie planowania obronnego a procesem realizacji cyklu planowania strategicznego w Polsce w latach 2015-2019?

Przystępując do rozwiązania problemów badawczych sformułowano następującą hipotezę roboczą: Istnienie regulacji prawnych w zakresie planowania obronnego samoistnie nie gwarantuje przestrzegania cyklu planowania strategicznego. Cykl ten w dużej mierze zależny jest od polityków odpowiedzialnych za procesy planowania. 


\section{PROCESY PLANOWANIA ORAZ PLANY W ZAKRESIE SPRAW OBRONNYCH}

\section{ZARZĄDZANIA KRYZYSOWEGO W POLSCE}

Realizatorzy szeroko rozumianych zadań związanych z bezpieczeństwem, ze względu na charakter i obszar ich działania czy też merytorycznej odpowiedzialności, włączani są, zgodnie z polskim ustawodawstwem, do różnych grup podmiotów uczestniczących bezpośrednio lub pośrednio $\mathrm{w}$ procesie zapewniania możliwości realizowania przez państwo jego funkcji wewnętrznej i zewnętrznej w obszarze zapewniania bezpieczeństwa wewnętrznego i zewnętrznego. Będą to m.in.:

- organy administracji wszystkich szczebli - realizujące zadania obronne i w zakresie obrony cywilnej ${ }^{2}$, czy też zarządzania kryzysowego ${ }^{3}$;

- podmioty o szczególnym znaczeniu gospodarczo-obronnym ${ }^{4}$;

- podmioty o istotnym znaczeniu dla gospodarki państwa ${ }^{5}$;

- podmioty wchodzące w skład systemów infrastruktury krytycznej ${ }^{6}$;

- podmioty, we właściwości których znajdują się obiekty szczególnie ważne dla bezpieczeństwa i obronności państwa ${ }^{7}$.

Proces realizacji zadań obronnych oraz zarządzania kryzysowego został usankcjonowany prawie. W zakresie realizacji zadań obronnych mówimy o planowaniu obronnym, a w zakresie realizacji zadań zarzadzania kryzysowego o planowaniu cywilnym.

Oprócz tych dwóch typów planowania, wykonywanych jest wiele zadań oraz opracowywane są na różnych szczeblach podziału administracyjnego państwa oraz przez różne podmioty, dokumenty planistyczne istotne $\mathrm{w}$ procesie zapewniania bezpieczeństwa państwa i obywateli. Są to m.in.:

\footnotetext{
${ }^{2}$ Podstawę prawną realizacji zadań stanowią postanowienia ustawy z dnia 21 listopada 1967 r. o powszechnym obowiazku obrony (Dz. U. z 2018 r. poz. 1459 z późn. zm.) oraz rozporządzenia wykonawcze, w tym zwłaszcza rozporządzenie Rady Ministrów z dnia 15 czerwca 2004 r. wsprawie warunków i trybu planowania $i$ finansowania zadań wykonywanych $w$ ramach przygotowań obronnych państwa przez organy administracji rzadowej i organy samorządu terytorialnego (Dz. U. z 2004 r. Nr 152, poz. 1599 z późn. zm.).

${ }^{3}$ Podstawę prawną realizacji zadań stanowią postanowienia ustawy z dnia 26 kwietnia 2007 r. o zarządzaniu kryzysowym (Dz. U. z 2019 r. poz. 1398).

${ }^{4}$ Podstawę prawną zaliczenia do tej grupy podmiotów stanowi ustawa $\mathrm{z}$ dnia 23 sierpnia $2001 \mathrm{r}$. o organizowaniu zadań na rzecz obronności państwa realizowanych przez przedsiębiorców (Dz. U. Nr 122, poz. 1320 z późn. zm.) oraz wydawane przez Ministra Obrony Narodowej w drodze decyzji „Wytyczne do przygotowania przez przedsiębiorców planu realizacji zadań obronnych, $w$ tym wynikajacych z Programu Mobilizacji Gospodarki, który stanowi plan operacyjny funkcjonowania przedsiębiorcy w warunkach zagrożenia bezpieczeństwa państwa i w czasie wojny".

${ }^{5}$ Podstawę prawną zaliczania do tej grupy podmiotów stanowi ustawa z dnia 16 grudnia 2016 r. o zasadach zarzadzania mieniem państwowym (Dz. U. poz. 2259 z późn. zm.) oraz rozporządzenie Prezesa Rady Ministrów z 13 stycznia 2017 r. w sprawie określenia wykazu spótek o istotnym znaczeniu dla gospodarki państwa (Dz. U. poz. 95).

${ }^{6}$ Podstawę prawną realizacji zadań stanowią postanowienia ustawy z dnia 26 kwietnia 2007 r. o zarządzaniu kryzysowym.

${ }^{7}$ Podstawę prawną zaliczania do tej grupy podmiotów stanowią postanowienia ustawy z dnia 22 sierpnia $1997 \mathrm{r}$. o ochronie osób i mienia (tekst jedn. Dz. U. z 2018 r., poz. 2142 z późn. zm.) oraz rozporządzenie Rady Ministrów z dnia 24 czerwca 2003 r. w sprawie obiektów szczególnie ważnych dla bezpieczeństwa i obronności państwa (Dz. U. nr 116, poz. 1090 z późn. zm.).
} 
- plany:

$\checkmark$ operacyjno-ratownicze, w tym: zewnętrzne - opracowywane przez Komendantów Wojewódzkich Państwowej Straży Pożarnej, oraz wewnętrzne - opracowywane przez przedsiębiorców prowadzących zakłady o dużym ryzyku;

$\checkmark$ gospodarki odpadami;

$\checkmark$ gospodarowania wodami;

$\checkmark$ ochrony dla obszarów podlegających ochronie;

$\checkmark$ przedsiębiorców telekomunikacyjnych w sytuacjach szczególnych zagrożeń;

$\checkmark$ działań operatorów pocztowych w sytuacji szczególnego zagrożenia;

$\checkmark$ ochrony dróg;

$\checkmark$ plany postępowania awaryjnego (w przypadku zdarzeń radiacyjnych);

$\checkmark$ działania systemu Państwowego Ratownictwa Medycznego;

$\checkmark$ zdrowotne;

$\checkmark$ operacyjne ochrony przed powodzią;

- programy:

$\checkmark$ przeciwdziałania awariom - opracowywane przez prowadzących zakłady o dużym i podwyższonym ryzyku wystąpienia awarii;

$\checkmark$ oczyszczania ścieków komunalnych;

$\checkmark$ ochrony środowiska;

$\checkmark$ ochrony powietrza wraz z planami krótko-, średnio- i długookresowymi;

$\checkmark$ ochrony środowiska przed hałasem;

- instrukcje bezpieczeństwa pożarowego;

- raporty o bezpieczeństwie.

Wśród wymienionych planów i programów tylko zewnętrzne i wewnętrzne plany operacyjno-ratownicze wykonywane na podstawie ustawy z dnia 27 kwietnia 2001 r. Prawo ochrony środowiska (tekst jednolity Dz. U z 2019 r. poz. 1369) opracowywane są w procesie nazwanego w ustawie planowania. Jest to planowanie ratownicze. W słowniku pojęć zawartym w ustawie proces planowania ratowniczego nie został jednak zdefiniowany. W ustawie mówi się tylko o kierowaniu się potrzebą zachowania jednolitości planowania ratowniczego $^{8}$. Ustawodawca określił jedynie częstość aktualizacji wewnętrznych planów operacyjno-ratowniczych - nie rzadziej niż co 3 lata9 .

\footnotetext{
${ }^{8}$ Art. 260 ust.3 ustawy zobowiązuje ministra właściwego do spraw wewnętrznych w porozumieniu z ministrem właściwym do spraw gospodarki, ministrem właściwym do spraw środowiska, ministrem właściwym do spraw administracji publicznej oraz Ministrem Obrony Narodowej, do określenia, w drodze rozporządzenia, wymagań, jakim powinny odpowiadać wewnętrzne i zewnętrzne plany operacyjno-ratownicze, kierując się potrzebą zapewnienia jednolitych zasad planowania ratowniczego.

${ }^{9}$ Art. 261 ust. 3 ustawy z dnia 27 kwietnia 2001 r. Prawo ochrony środowiska (tekst jednolity Dz. U. z 2019 r. poz. 1396) „Prowadzący zakład o dużym ryzyku jest obowiązany do przeprowadzania analizy i przećwiczenia realizacji wewnętrznego planu operacyjno-ratowniczego co najmniej raz na 3 lata, w celu jego aktualizacji i dokonania w nim uzasadnionych zmian; w szczególności należy brać pod uwagę zmiany wprowadzone w instalacji, w sposobie funkcjonowania jednostek ochrony przeciwpożarowej, stan wiedzy dotyczącej zapobiegania, zwalczania i usuwania skutków awarii przemysłowej, a także postęp naukowo-techniczny”.
} 
W zakresie pozostałych planów, programów i instrukcji, procesy planowania $\mathrm{w}$ tych obszarach nie zostały nazwane ani w ustawach, będących podstawą ich wykonywania, ani w rozporządzeniach czy też innych dokumentach normatywnych i wykonawczych niższej rangi.

Jakkolwiek obowiązujące obecnie mechanizmy i proces planowania obronnego zostały usankcjonowanie prawnie w 2004 r., pięć lat po wstąpieniu Polski do Sojuszu Północnoatlantyckiego (NATO), to źródła tych zmian leżą w procesie dochodzenia naszego kraju do członkostwa w NATO, a zwłaszcza w programie Partnerstwo dla Pokoju (Partnership for Peace - PfP). Na Szczycie Sojuszu Północnoatlantyckiego w Brukseli w styczniu 1994 r. państwom pretendującym do Sojuszu, przedstawiona została droga dochodzenia do członkostwa, w której istotną rolę odgrywał utworzony przez NATO program Partnerstwo dla Pokoju. Jednym $\mathrm{z}$ zasadniczych celów zawartych w podpisanym wówczas Dokumencie Ramowym PfP oraz podstawową kwestią, której wymagano od przyszłych członków Sojuszu było „działanie na rzecz przejrzystości w narodowym planowaniu obronnym” (... facilitation of transparency in national defence planning...." ${ }^{\text {"10 }}$.

Stworzenie przejrzystości procesu planowania obronnego w poszczególnych państwach dawnego bloku wschodniego miało pozwolić państwom starającym się o przyjęcie do Sojuszu na osiągnięcie w maksymalnym stopniu standardów planowania obowiązujących w państwach zachodnich, będących Członkami Sojuszu.

Jednocześnie na Szczycie NATO w dniach 8-9 lipca 1997 r. w Madrycie (na którym 16 Państw Członkowskich NATO zdecydowało o zaproszeniu Polski, Czech i Węgier do członkostwa w Sojuszu) kwestie zapewniania bezpieczeństwa ujęte zostały w założeniach Nowej Koncepcji Strategicznej NATO dotyczącej odejścia do dotychczasowej obowiązującej od 1967 r. doktryny „elastycznego reagowania"11 na rzecz doktryny „kooperatywnego bezpieczeństwa”. W Koncepcji znalazły się, oprócz kwestii typowo militarno-obronnych, mechanizmy reagowania kryzysowego oraz konieczność szerokiego ujmowania w procesie polityki obronnej m.in. nowych problemów Europy (przyczyny i konsekwencje wojny w Jugosławii), kwestii pozamilitarnych czy wręcz nieobronnych (rozwiązywanie kryzysów i planowanie obrony cywilnej), udziału w misjach pokojowych i humanitarnych, potrzeby działania w procesie kształtowani bezpieczeństwa i reagowania poza obszarem Państw Członkowskich, zwalczania terroryzmu oraz zagrożeń związanych z ewentualnym rozprzestrzenianiem się broni masowego rażenia ${ }^{12}$.

To ujęcie w procesie kształtowania i realizowania polityki obronnej kwestii problemów i zagrożeń pozamilitarnych wpisuje się w mechanizmy procesu planowania obronnego w Polsce

\footnotetext{
${ }^{10}$ J. Onyszkiewicz, Rola Planowania Polityki Obronnej, [w:] Seminar The Role of Defence Policy Planning, S. Helnarski, J. Szymanowska (red.), Warszawa 1998, s. 10 i 162.

${ }^{11}$ Demokratyczne zmiany zapoczątkowane przez „Solidarność” w Polsce w 1989 r., w następstwie których doszło do zmian w całej Europie Wschodniej oraz do rozwiązania Układu Warszawskiego oraz rozpadu Związku Socjalistycznych Republik Radzieckich pod koniec 1991 r., doprowadziły w listopadzie 1991 r. do decyzji NATO o potrzebie zmiany dotychczasowej doktryny obronnej. Nowa Koncepcja Strategiczna NATO została przyjęta 24 kwietnia 1999 r. na odbywającym się z okazji 50. rocznicy powstania NATO Szczycie w Waszyngtonie.

${ }^{12}$ Cf. J. Simon, Changing National Security Concept and Defence and Military Doctrines in Central and Eastern Europe, [w:] S. Helnarski, J. Szymanowska (red.), Seminar The Role ..., s. 17 i 169.
} 
wprowadzanymi zmianami ustawy o powszechnym obowiązku obrony Rzeczypospolitej Polskiej po przyjęciu Polski do NATO oraz pakietem rozporządzeń wykonawczych wprowadzonych w 2004 r.

Proces zmian mechanizmów planowania obronnego nie obejmował jednocześnie wszystkich kwestii i podmiotów zobowiązanych do realizacji zadań obronnych. Pewne zasadnicze zmiany następowały wraz ze zmianą systemu politycznego państwa po $1989 \mathrm{r}$. Dotyczy to np. procesów militaryzacji, która jest szczególną formą wykonywania i przygotowywania w czasie pokoju do skutecznego realizowania zadań obronnych przez podlegające militaryzacji cywilne podmioty administracyjne i gospodarcze ${ }^{13}$.

Tworzenie po 1989 r. mechanizmów gospodarki rynkowej oraz prywatyzacja wielu państwowych do tej pory przedsiębiorstw, które przed zmianami ustrojowymi stanowiły podstawę militaryzacji, spowodowały bardzo duże ograniczenia w procesie militaryzacji, a w zakresie sprywatyzowanych przedsiębiorstw wręcz ją uniemożliwiły.

Aby zapewnić państwu możliwość skutecznego przygotowania do funkcjonowania w warunkach zewnętrznego zagrożenia bezpieczeństwa i w czasie wojny niezbędne stały się zmiany legislacyjne. „W 1998 r., w wyniku nowelizacji ustawy o powszechnym obowiązku obrony Rzeczypospolitej Polskiej, zniesiono ograniczenie stosowania militaryzacji jedynie do państwowych jednostek organizacyjnych, a w $2001 \mathrm{r}$. stworzono ustawowe podstawy do ustalenia jednostek przewidzianych do militaryzacji przez Radę Ministrów, na wniosek ministrów i wojewodów"14. Tym samym sektor cywilny został włączony w system realizacji zadań remontowo-produkcyjnych, logistycznych i usługowych na rzecz Sił Zbrojnych RP i systemu obronnego państwa.

\section{CYKL PLANOWANia STRATEgiCZNego}

Cały proces przygotowania państwa do funkcjonowania i wypełniania swoich funkcji (wewnętrznej i zewnętrznej) nie tylko w czasie stanu gotowości obronnej państwa czasu pokoju, lecz także, a może zwłaszcza, w stanach gotowości obronnej państwa czasu kryzysu i stanu gotowości obronnej państwa czasu wojny ${ }^{15}$ jest uporządkowanym działaniem opierającym się na opisanych w aktach prawnych powinnościach, zadaniach i procesach planowania.

Koncepcja budowania i zapewniania bezpieczeństwa narodowego Polski oraz dokumenty opracowywane $\mathrm{w}$ procesie planowania obronnego powstają cyklicznie, a ich czasokres powstawania wynika z tzw. cyklu planowania strategicznego. Graficzne przedstawienie

\footnotetext{
${ }^{13}$ Militaryzacji podlegają podmioty, które przewidziane są do realizowania w warunkach zewnętrznego zagrożenia bezpieczeństwa państwa i w czasie wojny zadań związanych z rozwinięciem i skutecznym funkcjonowaniem systemu obronnego państwa.

${ }^{14}$ B. Rosa, A. Zalewski, Militaryzacja, „Wiedza Obronna”, Kwartalnik Towarzystwa Wiedzy Obronnej, Rok XXXIII, Nr 3/218, Warszawa 2006, s. 104.

${ }^{15}$ Stany gotowości obronnej państwa reguluje rozporządzenie Rady Ministrów z dnia 21 września 2004 r. w sprawie gotowości obronnej państwa (Dz. U. Nr 219, poz. 2218).
} 
cyklu planowania strategicznego pomiędzy strategiami bezpieczeństwa narodowego wydawanymi w latach 2007 i 2014 przedstawia rysunek 1 .

Cykl planowania strategicznego opiera się na zasadzie logicznie uporządkowanego powstawania dokumentów, z których każdy kolejny stanowi podstawę do opracowywania dokumentów wykonawczych zarówno w poszczególnych resortach, jak i na każdym szczeblu podziału administracyjnego państwa. Ustawodawca nie wskazał czasu, w jakim kolejne dokumenty powinny powstawać. Zakładano bowiem, że sprawy bezpieczeństwa narodowego będą priorytetem dla każdego ugrupowania politycznego sprawującego władzę w naszym kraju. Nie oznacza to, że kwestie te nie są regulowane żadnymi przepisami. Termin powstania dokumentów wynikających ze strategii bezpieczeństwa i wskazanych w polityczno-strategicznej dyrektywie obronnej zwarty jest w postanowieniu prezydenta o wydaniu dyrektywy.

\section{UWARUNKOWANIA PRAWNE WSPÓŁCZESNEGO PLANOWANIA ObRonNego W Polsce}

Stosownie do postanowień art. 2 ustawy z dnia 21 listopada 1967 r. o powszechnym obowiazku obrony Rzeczypospolitej Polskiej (Dz. U. z 2016 r. poz. 1534 z późn. zm.) „umacnianie obronności Rzeczypospolitej Polskiej, przygotowanie ludności i mienia narodowego na wypadek wojny oraz wykonywanie innych zadań w ramach powszechnego obowiązku obrony należy do wszystkich organów władzy i administracji rządowej oraz innych organów i instytucji państwowych, organów samorządu terytorialnego, przedsiębiorców i innych jednostek organizacyjnych, organizacji społecznych, a także do każdego obywatela w zakresie określonym w ustawach". Widzimy więc, że problem realizacji zadań obronnych i planowania obronnego nie jest kwestią, która dotyczy tylko resortu obrony narodowej. Jest powinnością wielu podmiotów oraz każdego obywatela ${ }^{16}$.

\footnotetext{
${ }^{16} \mathrm{~W}$ zakresie pojedynczych obywateli urzeczywistnia się on m.in. poprzez:

- realizację świadczeń osobistych lub rzeczowych, stosownie do postanowień ustawy z dnia 21 listopada 1967 r. o powszechnym obowiązku obrony Rzeczypospolitej Polskiej, obywatele polscy są obowiązani do wykonywania świadczeń na rzecz przygotowania obrony państwa na zasadach i w zakresie określonym w ustawie. Powinności te określa Dział VII Świadczenia na rzecz obrony, Rozdziały I i II, ustawy oraz rozporządzenia Rady Ministrów z dnia:

- 3 sierpnia 2004 r. w sprawie świadczeń rzeczowych na rzecz obrony w czasie pokoju (Dz. U. Nr 181, poz. 1872);

- 5 października 2004 r. w sprawie świadczeń osobistych na rzecz obrony w czasie pokoju (Dz. U. Nr 229, poz. 2307);

- $\quad$ czy też wykonywanie powinności wynikających z rozporządzenia Rady Ministrów z dnia 28 września 1993 r. o powszechnej samoobronie ludności (Dz. U. Nr 91, poz. 421 z późn. zm.).

Świadczenia osobiste i rzeczowe są nakładane również w razie mobilizacji i w czasie wojny - rozporządzenie Rady Ministrów z dnia 11 sierpnia 2004 r. w sprawie świadczeń osobistych i rzeczowych na rzecz obrony w razie ogłoszenia mobilizacji i w czasie wojny (Dz. U. Nr 203, poz. 2081).
} 


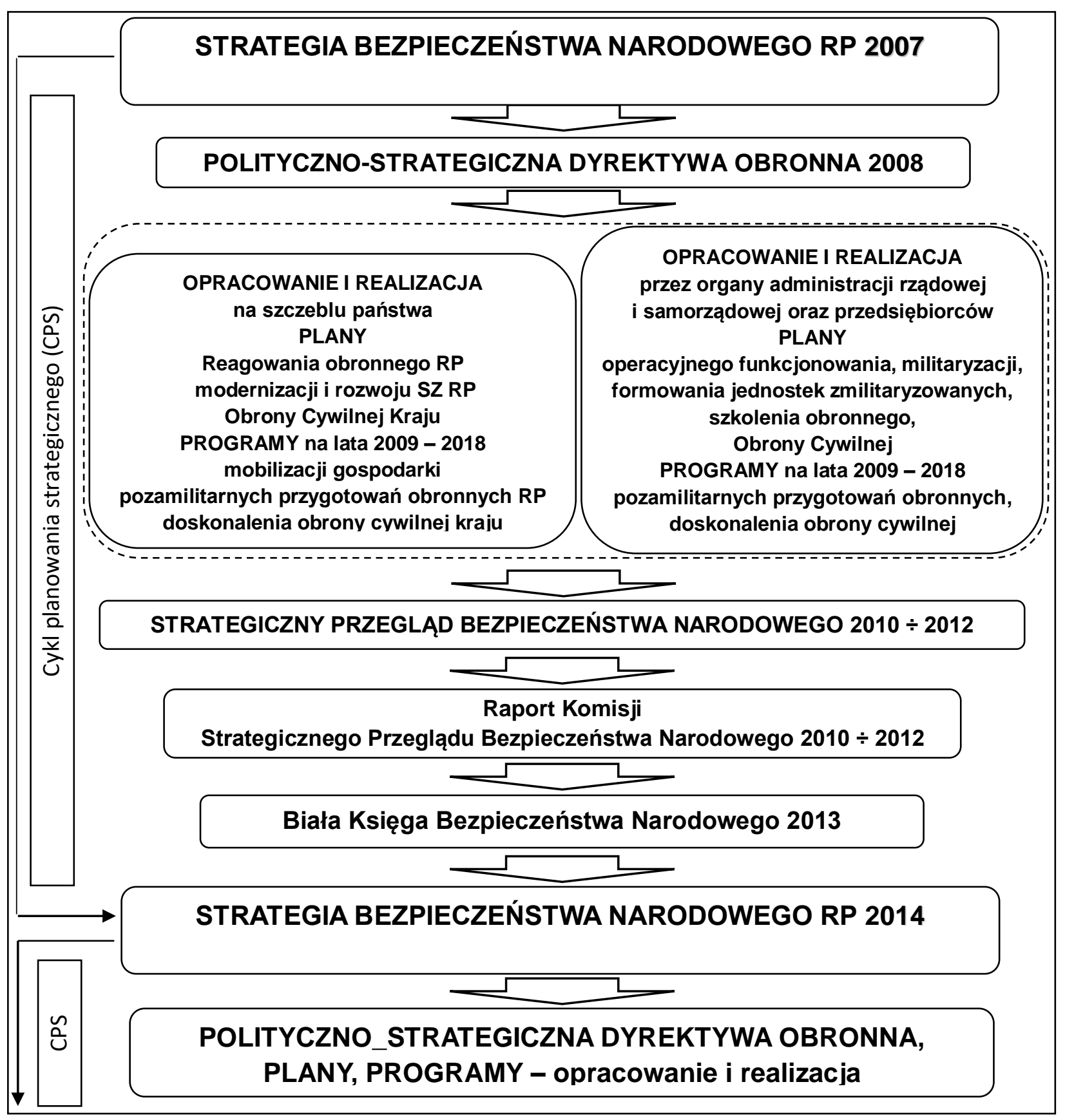

Rysunek 1. Cykl planowania strategicznego pomiędzy strategiami bezpieczeństwa narodowego wydawanymi w latach 2007 i 2014 Źródło: Opracowanie własne

Nie jest on uwarunkowany upływem lat, ale zmieniającymi się zagrożeniami bezpieczeństwa oraz sytuacją geopolityczną, w tym zwłaszcza w otoczeniu Rzeczypospolitej Polskiej. Rozpoczyna się on wraz w wydaniem nowej strategii bezpieczeństwa narodowego.

Zgodnie z rozporządzeniem Rady Ministrów z dnia 15 czerwca 2004 r. w sprawie warunków $i$ trybu planowania $i$ finansowania zadań wykonywanych $w$ ramach przygotowań obronnych państwa przez organy administracji rzadowej $i$ organy samorzadu terytorialnego mechanizm przygotowania podmiotów realizujących zadania w ramach powszechnego obowiązku obrony RP ujęto w proces planowania obronnego, który podzielono na dwa mechanizmy: 
1) planowania operacyjnego - polegający na wskazaniu niezbędnych czynności dotyczących przygotowania i działania organów administracji rządowej oraz organów samorządu terytorialnego $\mathrm{w}$ warunkach zewnętrznego zagrożenia bezpieczeństwa państwa i w czasie wojny. Czynności i działania ujmowane są w formie zestawów zadań operacyjnych ${ }^{17}$. Jednocześnie mechanizm planowania obejmuje proces określenia sił i środków niezbędnych do wykonania zadań operacyjnych ${ }^{18}$;

2) programowania obronnego - polegający na wskazaniu zadań obronnych realizowanych w czasie pokoju, na dziesięcioletni okres planistyczny, rozpoczynający się w roku nieparzystym, ujętych w formie przedsięwzięć rzeczowo-finansowych. Zadania te mają na celu utrzymanie i rozwój potencjału obronnego państwa oraz przygotowanie Sił Zbrojnych, organów administracji rządowej i organów samorządu terytorialnego do działania w warunkach zewnętrznego zagrożenia bezpieczeństwa państwa i w czasie wojny. Proces zawiera również projektowanie środków budżetowych przeznaczonych na realizację zadań obronnych.

Ustawodawca zdefiniował pojęcie planowania obronnego jako „ustalanie sposobów wykonywania zadań obronnych przez organy administracji rządowej i organy samorządu terytorialnego oraz wykorzystania w tym celu niezbędnych sił i środków, obejmujące planowanie operacyjne i programowanie obronne"19.

Jednocześnie realizacja zadań planowania obronnego nie jest wyodrębnionym i niezależnym od merytorycznego obszaru odpowiedzialności działaniem, lecz integralną częścią funkcjonowania instytucji. Uwzględnia uwarunkowania zewnętrzne i wewnętrzne funkcjonowania organu realizującego zadania obronne. Uwarunkowania zewnętrzne i wewnętrzne oraz miejsce planowania obronnego w realizacji zadań organu władzy publicznej przedstawia rysunek 2, a podział planowania obronnego i rodzaje dokumentów wykonywanych w procesie planowania przedstawia rysunek 3 .

\footnotetext{
${ }^{17}$ „Zestaw zadań operacyjnych - to usystematyzowane zadania operacyjne przewidziane do realizacji określonego ministra kierującego działem administracji rządowej, centralny organ administracji rządowej, wojewodę, kierownika jednostki organizacyjnej podległej lub nadzorowanej przez Prezesa Rady Ministrów albo ministra, albo też określoną grupę tych podmiotów, przy pomocy podległych i nadzorowanych jednostek organizacyjnych, a w przypadku wojewodów również przy pomocy marszałków województw, starostów, prezydentów miast, wójtów i burmistrzów oraz jednostek organizacyjnych utworzonych przez jednostki samorządu terytorialnego" - § 2 pkt 5 rozporządzenia Rady Ministrów z dnia 15 czerwca 2004 r. w sprawie warunków i trybu planowania i finansowania zadań wykonywanych $w$ ramach przygotowań obronnych państwa oraz przez organy administracji rzadowej $i$ organy samorzadu terytorialnego (Dz. U. nr 152, poz. 1599 z późn. zm.).

${ }^{18}$ Zadania operacyjne - ta część zadań obronnych, które są realizowane w warunkach zewnętrznego zagrożenia bezpieczeństwa państwa i w czasie wojny - $\S 2$ pkt 4 rozporządzenia Rady Ministrów z dnia 15 czerwca 2004 r. w sprawie warunków i trybu planowania i finansowania...

$19 \S 2$ pkt 6 rozporządzenia Rady Ministrów z dnia 15 czerwca 2004 r. w sprawie warunków i trybu planowania i finansowania... (Dz. U. nr 152, poz. 1599).
} 


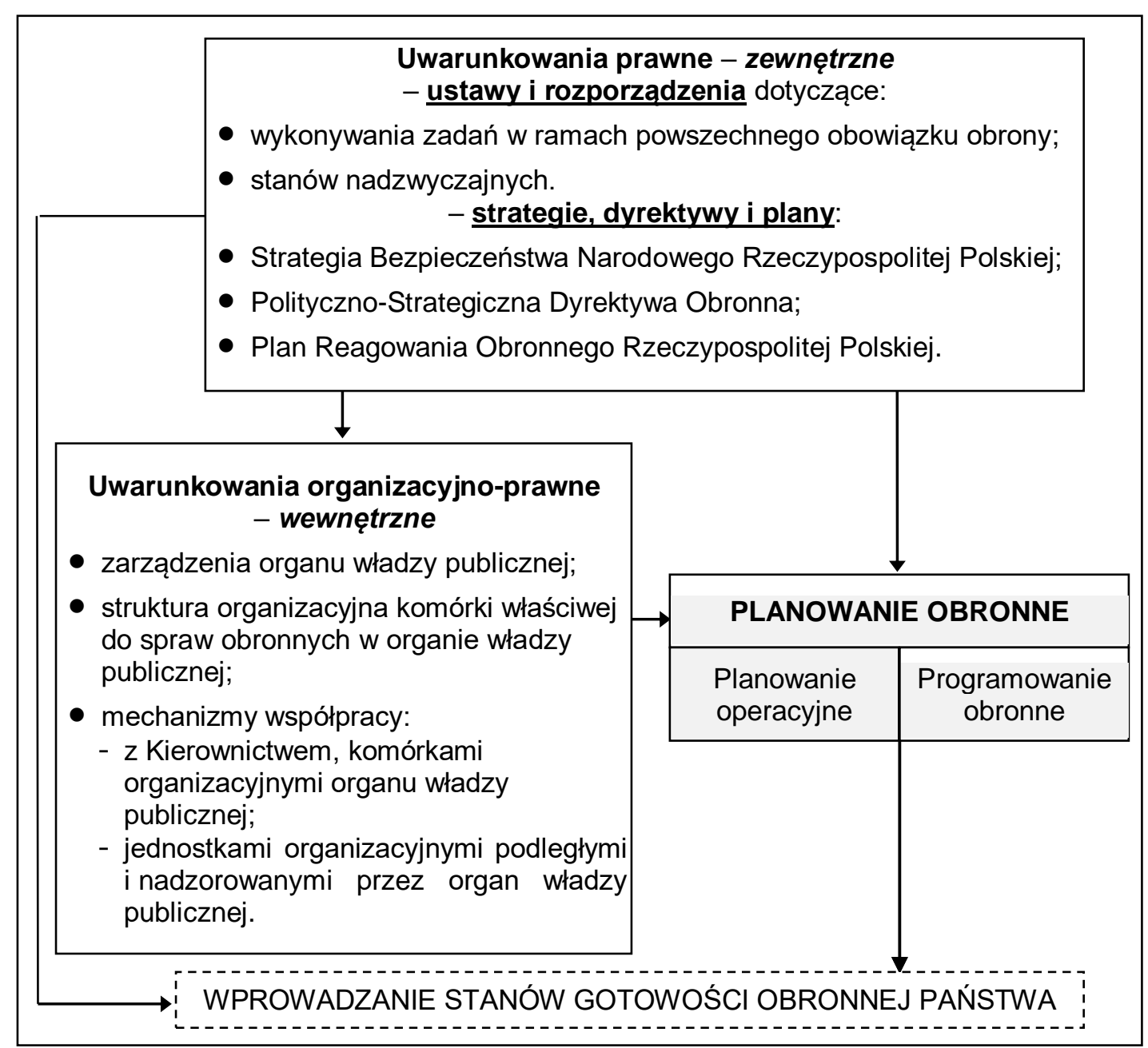

Rysunek 2. Uwarunkowania zewnętrzne i wewnętrzne oraz miejsce planowania obronnego w procesie realizacji zadań organu władzy publicznej

Źródło: Opracowanie własne na podstawie: T. Kęsoń, Planowanie operacyjne w procesie realizacji zadań obronnych na przykladzie Ministerstwa Pracy i Polityki Spolecznej - wybrane problemy [w:] K. Meszyński (red.), Projektowanie planowania operacyjnego $w$ administracji publicznej wobec wyzwań i zagrożeń bezpieczeństwa narodowego, Warszawa 2014, s. 135. 


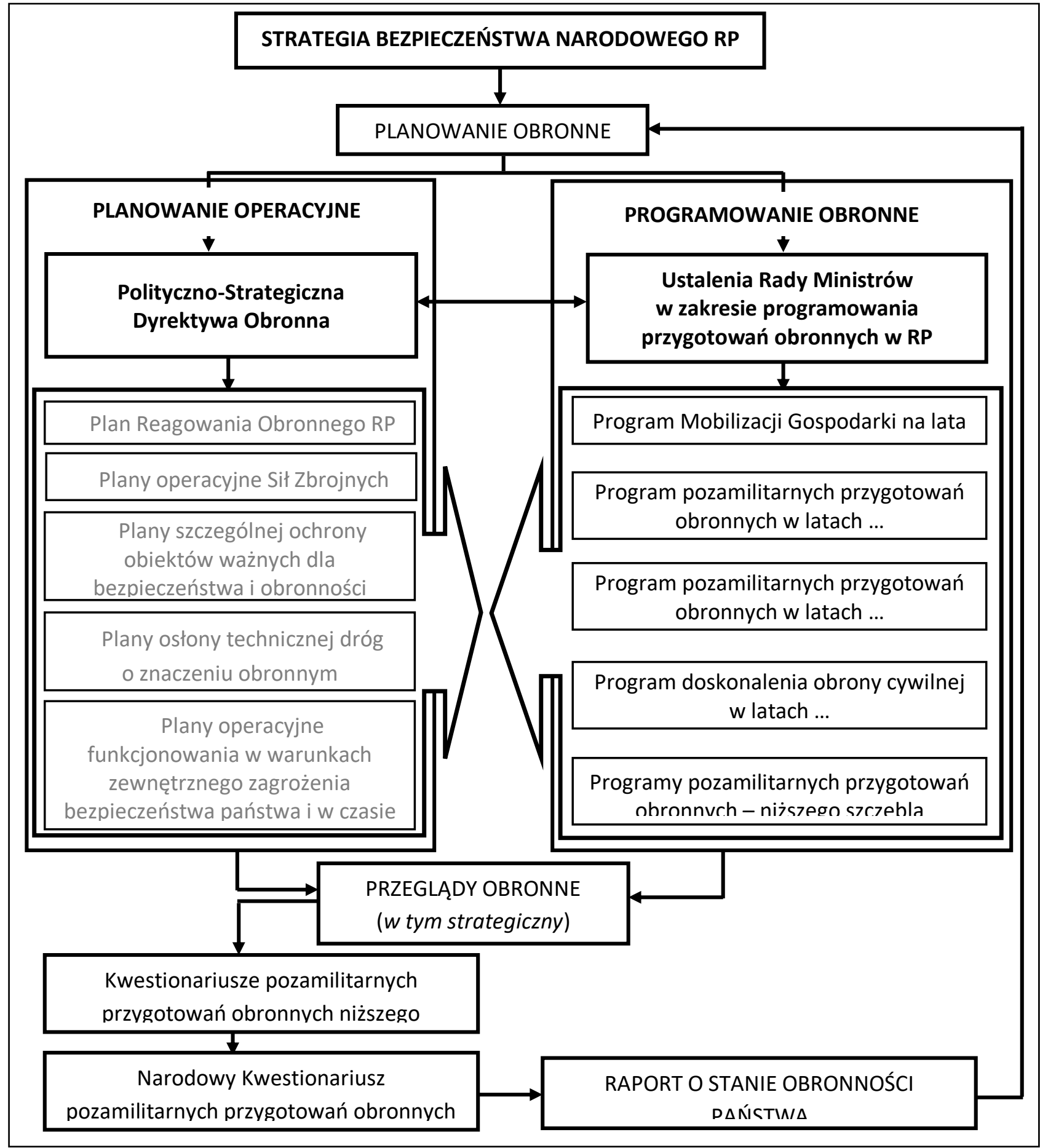

Rysunek 3. Planowanie obronne - podział ogólny i rodzaje dokumentów wykonywanych w procesie planowania Źródło: Opracowanie własne - na podstawie rozporządzenia Rady Ministrów z dnia 15 czerwca 2004 r. w sprawie warunków i trybu planowania i finansowania zadań wykonywanych w ramach przygotowań obronnych państwa przez organy administracji rządowej i organy samorządu terytorialnego (Dz. U. nr 152, poz. 1599 z późn. zm.).

Zasadniczym celem całego procesu planowania jest przygotowanie instytucji do funkcjonowania $\mathrm{w}$ warunkach zagrożeń zewnętrznego bezpieczeństwa państwa i w czasie wojny. Ponieważ ustawy z dnia 21 czerwca 2002 r. o stanie wyjątkowym (Dz. U. z 2017 r. poz. 1928 tekst jednolity) - art. 8 oraz z 29 sierpnia 2002 r. o stanie wojennym oraz o kompetencjach Naczelnego Dowódcy Sit Zbrojnych $i$ zasadach jego podległości konstytucyjnym organom 
Rzeczypospolitej Polskiej (Dz. U. z 2017 r. poz. 1932 - tekst jednolity) - art. 9 określając zasady funkcjonowania władzy publicznej jednoznacznie stwierdzają, że w stanach tych „organy władzy publicznej działają $\mathrm{w}$ dotychczasowych strukturach organizacyjnych państwa i w ramach przysługujących im kompetencji, z zastrzeżeniem przepisów niniejszych ustaw”, zatem przygotowanie wszystkich komórek organizacyjnych podmiotu realizującego zadania obronne jest zadaniem szczególnie ważnym.

Ponieważ skuteczność i zasadność planowania obronnego urzeczywistniają się i nabierają znaczenia dopiero w warunkach zewnętrznego zagrożenia bezpieczeństwa państwa, jest ono niestety bardzo często nie tylko nie w pełni właściwie postrzegane przez organy decyzyjne w instytucjach, lecz wręcz lekceważone. Przejawia się to przede wszystkim w pojmowaniu realizacji zadań obronnych jako powinności jedynie komórki, której zadania te zostały w dokumentach organizacyjnych przypisane (jeżeli takowa została utworzona - bardzo często są to bowiem jedynie pojedyncze stanowiska pracy, bądź zadania te wykonywane są jako część etatu wskazanego pracownika), a nie całości instytucji. Zapomina się bowiem o tym, że to cała instytucja, a nie tylko komórka właściwa w sprawach obronnych ma funkcjonować i realizować zadania w warunkach zagrożeń.

\section{Planowanie CYWILNe}

Mechanizmy planowania cywilnego, które jest domeną zarządzania kryzysowego, uregulowane zostały ustawą z dnia 26 kwietnia 2007 r. o zarządzaniu kryzysowym (Dz. U. Nr 89 poz. 590).

Ustawodawca w art. 3 pkt 4 ustawy zdefiniował pojęcie planowania cywilnego w dwóch obszarach odnoszących się do:

1) sfery administracji publicznej - rozumiane jako całokształt przedsięwzięć organizacyjnych polegający na opracowywaniu planów, w tym planów reagowania kryzysowego i programów mających na celu optymalne wykorzystanie dostępnych sił i środków w sytuacjach kryzysowych oraz w czasie stanów nadzwyczajnych i w czasie wojny, w zakresie zapobiegania sytuacjom kryzysowym, przygotowania do przejmowania nad nimi kontroli, reagowania w sytuacjach kryzysowych oraz odtwarzania infrastruktury i przywracania jej pierwotnego charakteru;

2) udziału i użycia sił zbrojnych - rozumiane jako planowanie w zakresie wspierania sił zbrojnych RP w razie ich użycia oraz planowanie wykorzystania sił zbrojnych do realizacji zadań zarządzania kryzysowego.

Ujęcie w definicji planowania cywilnego czasu, w którym wprowadzane są rozwiązania szczególne i wykorzystywane narzędzia konstytucyjnych stanów nadzwyczajnych, mogłoby wskazywać na zastosowane uniwersalnego podejścia do przygotowania państwa i jego struktur do działania w maksymalnie szerokim spektrum zdarzeń i sytuacji nie tylko w zakresie bezpieczeństwa wewnętrznego (stan klęski żywiołowej, stan wyjątkowy), lecz 
także zewnętrznego (stan wojenny), z zastosowanej definicji planowania cywilnego jasno wynika bowiem, że sytuacje kryzysowe to nie tylko zagrożenia i zdarzenia o różnym podłożu i intensywności, a w których przeciwdziałaniu, minimalizowaniu oraz zwalczaniu skutków uczestniczą tylko podmioty administracji publicznej wszystkich szczebli oraz podległe im służby, inspekcje i straże, ale mogą również uczestniczyć organizacje międzynarodowe i podmioty, w tym np. Organizacja Traktatu Północnoatlantyckiego (NATO).

Takie podejście do zarządzania kryzysowego jest skutkiem zmieniającego się i trwającego $\mathrm{w}$ nieustającym procesie zmian środowiska bezpieczeństwa, ewaluowania i nakładania się na siebie przyczyn współczesnych zagrożeń bezpieczeństwa. Charakterystykę zmian środowiska bezpieczeństwa „wiernie oddaje wypowiedź Javiera Solany: Zagrożenia i wyzwania XXI w. są różne od tych, w których wyrośliśmy w czasach zimnej wojny [...]. Dzisiejszy świat już tak nie działa [...]. Granice pomiędzy bezpieczeństwem wewnętrznym i zewnętrznym, policją i wojskiem, zapobieganiem kryzysom oraz ich rozwiązywaniem, walką z kryminalną i finansową przestępczością, tropieniem terroryzmu i radzeniem sobie z upadającymi reżimami stają się z sztuczne i niewyraźne"20.

Jakkolwiek zasadnicze działania NATO, w pojmowaniu przeciętego człowieka - jako biorcy bezpieczeństwa, koncentrują się na przeciwdziałaniu kryzysom, które mogą skutkować wybuchem konfliktów zbrojnych, nie należy zapominać o prowadzeniu przez Sojusz operacji humanitarnych, wspierania i ochraniania ich przez siły zbrojne państw członkowskich Sojuszu czy też o całym spektrum prowadzonych operacji pokojowych (peace making, peace keeping, peace enforcement czy też peace operations other than war). Przyczyny tych działań bardzo często wymagają w krajach dotkniętych kryzysem podejmowania nadzwyczajnych działań, skutkujących m.in. różnymi ograniczeniami praw obywateli wynikającymi z wprowadzanych stanów nadzwyczajnych. Działania te ze względu na ich charakter i użycie sił zbrojnych pozornie wykraczają poza ramy „,cywilnego” zarządzania kryzysowego.

Taki sztuczny podział działań czy też granicę zaliczania bądź uznawania danej sytuacji za sytuację kryzysową wprowadzała w Polsce również ustawa o zarządzaniu kryzysowym z 2007 r. w swoim pierwotnym brzmieniu. Z jednej strony szeroki obszar ujęty definicji planowania cywilnego, a $\mathrm{z}$ drugiej zawężająca je definicja sytuacji kryzysowej. Postanowienia art. 3 pkt 1 ustawy definiowały sytuację kryzysową, jako „będącą następstwem zagrożenia i prowadzącą w konsekwencji do zerwania lub znacznego naruszania więzów społecznych pry równoczesnym poważnym zakłóceniu funkcjonowania instytucji publicznych, jednak w takim stopniu, że użyte środki niezbędne do zapewnienia lub przywrócenia bezpieczeństwa nie uzasadniają wprowadzenia żadnego ze stanów nadzwyczajnych". Podział ten został zlikwidowany po postanowieniu Trybunału Konstytucyjnego, który uznał art. 3 pkt 1 za

\footnotetext{
${ }^{20}$ T. Kęsoń, Zarzadzanie kryzysowe w Polsce, [w:] Zarzadzanie kryzysowe elementem bezpieczeństwa narodowego Rzeczypospolitej Polskiej - praca zbiorowa, R. Kuriata (red.), Piotrków Trybunalski 2014 r., s. 79-80.
} 
niezgodny $\mathrm{z}$ art. 2 Konstytucji Rzeczypospolitej Polskiej ${ }^{21}$. Wprowadzona w konsekwencji rozstrzygnięcia Trybunału nowelizacja ustawy z 2009 r. usunęła to ograniczenie. Wprowadzono zapis, że za „sytuację kryzysową należy rozumieć sytuację negatywnie wpływającą na poziom bezpieczeństwa ludzi, mienia i środowiska, wywołującą znaczne ograniczenia w działalności właściwych organów administracji publicznej, ze względu na nieadekwatność posiadanych sił i środków" 22 .

Ponadto w 2009 r. skrócono i zmieniono ustawową definicję planowania cywilnego w obszarze administracji publicznej, w której wprost napisano, że planowanie cywilne to „całokształt przedsięwzięć organizacyjnych mających na celu przygotowanie administracji publicznej do zarządzania kryzysowego"23. Z ustawy usunięto rozbieżność między definicją sytuacji kryzysowej a planowania cywilnego w zakresie funkcjonowania państwa w warunkach wykorzystywania konstytucyjnych rozwiązań szczególnych, jakimi są stany nadzwyczajne, a ponadto wskazano na spójność działań w procesie planowania cywilnego z działaniami.

Jednocześnie w art. 4. ust. 1. wskazano cztery zadania z zakresu planowania cywilnego, które obejmują ${ }^{24}$ :

1) przygotowanie planów zarządzania kryzysowego;

2) przygotowanie struktur uruchamianych w sytuacjach kryzysowych;

3) przygotowanie rozwiązań na wypadek zniszczenia lub zakłócenia funkcjonowania infrastruktury krytycznej;

4) przygotowanie i utrzymywanie zasobów niezbędnych do wykonania zadań ujętych w planie zarządzania kryzysowego;

5) utrzymywanie baz danych niezbędnych w procesie zarządzania kryzysowego;

6) zapewnienie spójności między planami zarządzania kryzysowego a innymi planami sporządzanymi w tym zakresie przez właściwe organy administracji publicznej, których obowiązek wykonania wynika z odrębnych przepisów.

$\mathrm{Z}$ punktu widzenia planowania operacyjnego i planowania cywilnego istotny jest zapis dotyczący zachowania spójności między opracowywanymi w tych procesach planami. Wskazuje on jednoznacznie, że wszelkie plany dotyczące działania państwa w różnych możliwych do zaistnienia sytuacjach nie mogą ani się wykluczać, ani tworzyć odrębnych niespójnych rozwiązań, a działanie powinno płynnie przechodzić z realizacji przedsięwzięć zawartych w planach zarządzania kryzysowego do przedsięwzięć zawartych w planach operacyjnego funkcjonowania.

W procesie planowania cywilnego, dla potrzeb skutecznego realizowania zadań zarządzania kryzysowego w zależności od poziomu, na którym funkcjonuje system zarzadzania kryzysowego, przewidziano opracowywanie dwóch dokumentów:

\footnotetext{
${ }^{21}$ Wyrok Trybunału Konstytucyjnego z dnia 21 kwietnia 2009 r. Sygnatura akt: 50/07 (Dz. U. z 2009 r. Nr 65 , poz. 533).

${ }^{22}$ Ustawa z dnia 17 lipca 2009 r. o zmianie ustawy o zarzadzaniu kryzysowym (Dz. U. z 2009 r. Nr 131, poz. 1076).

${ }^{23}$ Ibidem, art. 3 pkt 4.

${ }^{24}$ Art. 4 ust. 1. Ustawy z dnia 26 kwietnia 2017 r. o zarządzaniu kryzysowym (tj. Dz. U. z 2019 r. poz. 1398).
} 
1) na szczeblu państwa:

- Raport o zagrożeniach bezpieczeństwa narodowego - opracowanie Raportu koordynuje Dyrektor Rządowego Centrum Bezpieczeństwa $(\mathrm{RCB})^{25}$, z uwzględnieniem, że w części dotyczącej zagrożeń:

terrorystycznych za koordynację odpowiada Szef Agencji Bezpieczeństwa Wewnętrznego;

$\checkmark$ cyberbezpieczeństwa za koordynację odpowiada Pełnomocnik Rządu do spraw Cyberbezpieczeństwa,

- Krajowy Plan Zarządzania Kryzysowego;

2) na szczeblu resortowym - opracowują ministrowie, kierownicy urzędów centralnych i wojewodowie:

- raporty „cząstkowe” o zagrożeniach bezpieczeństwa narodowego, będące podstawą opracowania przez Dyrektora RCB Raportu o zagrożeniach bezpieczeństwa narodowego;

- plany zarządzania kryzysowego;

3) na szczeblu powiatu i gminy - opracowują starostowie, wójtowie (prezydenci miast):

- plany zarządzania kryzysowego.

Dla potrzeb opracowania planów zarządzania kryzysowego wydawane są przez poszczególne podmioty wytyczne lub zalecenia, w tym:

- minister właściwy w sprawach wewnętrznych wydaje wojewodom w drodze zarządzenia wytyczne do opracowania wojewódzkich planów zarządzania kryzysowego;

- wojewoda wydaje starostom zalecenia do opracowania powiatowych planów zarządzania kryzysowego;

- starostowie wydają organom gminy zalecenia do opracowania gminnych planów zarządzania kryzysowego.

Jakkolwiek nie wynika to $\mathrm{z}$ żadnego aktu prawnego, w celu ujednolicenia zawartości planów zarządzania kryzysowego na szczeblu resortowym Dyrektor Rządowego Centrum Bezpieczeństwa przekazuje wykonawcom planów „Wytyczne do opracowania planów zarządzania kryzysowego". Wytyczne te są swoistym przewodnikiem ułatwiającym opracowanie planów, ale nie muszą być przestrzegane przez opracowującego plany.

Zawartość planów zarządzania kryzysowego wszystkich szczebli określa ustawa o zarządzaniu kryzysowym. Zgodnie z postanowieniami art. 5 ust. 3 ustawy plany zarządzania kryzysowego podlegają systematycznej aktualizacji, a cykl planowania nie może być dłuższy niż dwa lata.

W zakresie natomiast Raportu o zagrożeniach bezpieczeństwa narodowego sposób, tryb i terminy jego opracowywania określa Rada Ministrów w drodze rozporządzenia.

Ponadto $\mathrm{w}$ procesie planowania cywilnego przygotowywane są:

\footnotetext{
${ }^{25}$ Raport o zagrożeniach bezpieczeństwa narodowego jest podstawą opracowania Krajowego Planu Zarządzania Kryzysowego.
} 
1) Narodowy Program Ochrony Infrastruktury Krytycznej - przez Dyrektora RCB, we współpracy z ministrami i kierownikami urzędów centralnych odpowiedzialnych za systemy infrastruktury krytycznej oraz właściwymi w sprawach bezpieczeństwa narodowego (art. 5b, ust. 3 ustawy);

2) plany ochrony infrastruktury krytycznej - przez właścicieli oraz posiadaczy samoistnych i zależnych obiektów, instalacji lub urządzeń infrastruktury krytycznej (art. 6, ust. 5 ustawy).

Dynamiczne, nie zawsze pozytywne zmiany w stosunkach wewnętrznych i zewnętrznych poszczególnych państw, zwłaszcza w obliczu wielostronnych działań, które prowadzić mogą do negatywnych skutków, w wyniku zjawiska „dylematu bezpieczeństwa”, jednoznacznie wskazują, że sytuacje kryzysowe obejmują również obszary kryzysów polityczno-militarnych i nie mogą być wyłączane z obszaru planowania cywilnego.

\section{ZABURZENIA I OPÓŹNIENIA REALIZACJI CYKLU PLANOWANIA STRATEGICZNEGO W LATACH 2015-2019}

Wydawać by się mogło, że procesy zapewniania bezpieczeństwa narodowego, nie powinny podlegać procesom koniunkturalizmu, sporom kompetencyjnym. Można w jakiś sposób wskazywać przyczyny sporów i powstawania opóźnień w procesie planowania w związku ze zjawiskiem kohabitacji. Trudno jednak zrozumieć powstawanie opóźnień czy też całkowite wstrzymywanie procesów planowania obronnego w momencie, kiedy prezydent, premier i minister obrony narodowej są z jednego ugrupowania politycznego. Niestety lata 2015-2019 pokazały, że takie zjawisko zachodzi, a kwestie bezpieczeństwa opierające się na procesie planowania obronnego mogą być ignorowane.

Przedstawiony na schemacie cykl z lat 2007-2013 pokazuje, że poszczególne etapy cyklu i powstawanie dokumentów planistycznych, jakkolwiek z drobnymi opóźnieniami, nie napotykało przeszkód i planowanie odbywało się bez zakłóceń. Opublikowanie „nowej” Strategii Bezpieczeństwa Narodowego nastąpiło w 2007 r. Prezydent Rzeczypospolitej Polskiej Lech Kaczyński wydał postanowienie o wydaniu Polityczno-Strategicznej Dyrektywy Obronnej 16 lipca 2009 r. (M.P. Nr 48, poz. 705) ${ }^{26}$. Plan reagowania obronnego został opracowany w tym samym roku. Planowanie operacyjne $\mathrm{w}$ resortach i administracji rządowej rozpoczęto na przełomie 2009/2010 r. i zakończono w 2010 r. Na szczeblu administracji samorządowej oraz w jednostkach organizacyjnych podległych i nadzorowanych przez ministrów proces ten został zakończony w 2011 r. Po trzech latach obowiązywania Strategii rozpoczęto Strategiczny

\footnotetext{
${ }^{26}$ Postanowienie Prezydenta Lecha Kaczyńskiego uchyliło poprzednią Dyrektywę, wprowadzoną przez Prezydenta Aleksandra Kwaśniewskiego postanowieniem z dnia 12 marca 2004 r. o wydaniu PolitycznoStrategicznej Dyrektywy Obronnej Rzeczypospolitej Polskiej (M. P. Nr 16, poz. 255).
} 
Przegląd Bezpieczeństwa Narodowego ${ }^{27}$, którego wynikiem były m.in. wnioski do nowej strategii bezpieczeństwa.

Zupełnie inny obraz realizacji cyklu strategicznego mamy po opublikowaniu Strategii Bezpieczeństwa Narodowego z 2014 r. Pomimo tego, że ówczesny Prezydent RP Bronisław Komorowski, na wniosek Prezesa Rady Ministrów, postanowieniem z dnia 17 lipca 2015 r. wydał Polityczno-Strategiczną Dyrektywę Obronną 28 (M.P. poz. 697), proces planowania obronnego przez nowo wybranego (po wyborach w październiku w 2015 r.) Ministra Obrony Narodowej nie został uruchomiony $^{29}$. Zignorowano i nie przestrzegano żadnych postanowień Dyrektywy, która w $\S 2$ ust. 2 stwierdzała, że „Plany oraz inne dokumenty wykonawcze wydane na podstawie Polityczno-Strategicznej Dyrektywy Obronnej Rzeczypospolitej Polskiej, [...] obowiązują do czasu wydania nowych planów i dokumentów wykonawczych według ustaleń przyjętych w dyrektywie, nie dłużej niż 10 miesięcy od daty wejścia w życie postanowienia".

Istotą Polityczno-Strategicznej Dyrektywy Obronnej z 2015 r. było to, że określała ona zadania dla wszystkich struktur państwa na czas zagrożenia i wojny, uwzględniające także nowe formy zagrożeń (w tym asymetrycznych, oraz agresję poniżej progu wojny). Przy takim ujęciu zagrożeń i możliwości rozwoju sytuacji polityczno-militarnej, w której państwo nasze mogłoby się znaleźć, rozpoczęcie procesu planowania obronnego w państwie, tak jak to stanowi ustawa o powszechnym obowiązku obrony, wydawało się naturalną koleją rzeczy. Niestety proces planowania nie został uruchomiony. Co więcej, wydawanie kolejnych dokumentów zarówno przez Prezydenta RP, jak i rząd oraz Ministra Obrony Narodowej pokazuje, że cykl planowania strategicznego przestał funkcjonować, a sprawy bezpieczeństwa są W zasadzie pustym frazesem w ustach rządzących. Ewenementem w procesie zatrzymanego procesu planowania jest również to, że do tej samej strategii, która po upływie ponad czterech lat od wydania nie jest już w pełni adekwatna do sytuacji politycznomilitarnej w bliższym i dalszym otoczeniu Polski, wydaje się drugą polityczno-strategiczną dyrektywę obronną. Prezydent Andrzej Duda podpisał postanowienie o wydaniu PolitycznoStrategicznej Dyrektywy Obronnej dopiero 29 grudnia 2018 r. (M.P. z 2019 r. poz. 15) tj. cztery i pół roku po opublikowaniu Strategii Bezpieczeństwa Narodowego z 2014 r. ${ }^{30}$

\footnotetext{
${ }^{27}$ Strategiczny Przegląd Bezpieczeństwa Narodowego realizowany w latach 2010-2012 był pierwszym tego typu przeglądem. Do tej pory weryfikacja realizacji zadań wynikających ze strategii i jej aktualność realizowana była w oparciu o Strategiczne Przeglądy Obronne.

${ }^{28}$ Dyrektywa wydawana na podstawie art. 4a ust. 1 pkt. 2 ustawy o powszechnym obowiazku obrony Rzeczypospolitej Polskiej jest niejawnym dokumentem wykonawczym do Strategii Bezpieczeństwa Narodowego RP.

${ }^{29}$ Władzę po koalicji Platformy Obywatelskiej z Polskim Stronnictwem Ludowym, objęła koalicja partii: Prawo i Sprawiedliwość, Solidarna Polska i Polska Razem, a ministrem obrony narodowej został Antoni Macierewicz.

${ }^{30}$ Postanowienie weszło w życie 7 stycznia 2019 r. Jednocześnie w Postanowieniu skrócono zwyczajowo przyjmowany do tej pory 10-miesięczny okres obowiązywania dotychczasowych dokumentów i opracowania nowych planów i dokumentów wykonawczych wskazanych w dyrektywie do:

- 9 miesięcy - od dnia wejścia w życie postanowienia w przypadku planów i dokumentów wydanych przez ministrów, centralne organy administracji rządowej, kierowników jednostek organizacyjnych podległych lub nadzorowanych przez Prezesa Rady Ministrów, a także wojewodów;

- 18 miesięcy - od dnia wejścia w życie postanowienia w przypadku planów i dokumentów wydanych przez organy i jednostki organizacyjne niższego szczebla.
} 
Naiwnością jest sądzenie, że te dwa dokumenty są adekwatne do zagrożeń, wyzwań oraz interesów narodowych wskazanych w Strategii Bezpieczeństwa Narodowego z 2014 r.

Przecież dynamicznie zmieniające się środowisko strategicznego bezpieczeństwa czy też radykalnie i turbulencyjnie zmienny porządek międzynarodowy nie omijają Polski. Zmieniają się czynniki kształtujące i kreujące środowisko bezpieczeństwa ${ }^{31}$, a dokumenty planistyczne powinny odzwierciedlać kształt bezpieczeństwa i odpowiadać na wyzwania, z jakimi może zmierzyć się nasz kraj. Zapewnienie i utrzymywanie bezpieczeństwa i skuteczne reagowanie adekwatnych do wyzwań komponentów systemu obronności państwa będzie tym łatwiejsze, im pełniej w procesie planowania odniesiemy się do wskazanych w dokumentach strategicznych zagrożeń bezpieczeństwa a w procesach prognozowania przewidzimy i poznamy niezidentyfikowane jeszcze zagrożenia $^{32}$.

Taki długi okres czasu, jaki upłynął pomiędzy wydaniem tych dwóch dokumentów, pokazuje, że proces planowania obronnego w Polsce został przez sprawujących władzę wykonawczą zignorowany i zatrzymany. Cała administracja rządowa i samorządowa nie mogła realizować procesów planowania i opracowywać dokumentów, które zapewniałyby możliwość ich funkcjonowania w sytuacji zagrożeń wskazanych w Strategii z 2014 r. oraz w warunkach zewnętrznego zagrożenia bezpieczeństwa państwa i w czasie wojny, ponieważ Ministerstwo Obrony Narodowej ${ }^{33}$ nie opracowało ostatecznej wersji Planu Reagowania Obronnego Rzeczypospolitej Polskiej (PRO RP) i nie uzgodniło zadań obronnych z poszczególnymi ministrami, organami centralnymi i wojewodami oraz nie przekazało wypisów PRO RP oraz zestawów zadań do poszczególnych ministerstw i wojewodów - a dopiero te dokumenty stanowią podstawę rozpoczęcia planowania obronnego na tych szczeblach władzy.

Do wydanej w grudniu 2018 r. przez Prezydenta RP PSDO, Minister Obrony Narodowej wydał Wytyczne do planowania operacyjnego i przygotowania przedsiębiorców do funkcjonowania $w$ warunkach zewnętrznego zagrożenia bezpieczeństwa państwa $i \backslash w$ czasie wojny - Dec. MON nr 82/MON z dnia 17 maja 2019 r. (Dz. U. MON z 2019 poz. 105), w których skrócono termin opracowania planów operacyjnych na szczeblu ministerstw i urzędów centralnych do trzech miesięcy. Zaznaczyć jednocześnie należy, że w tym samym

Widzimy więc, że na szczeblu administracji rządowej proces planowania operacyjnego zakończy się na miesiąc przed wyborami parlamentarnymi zaplanowanymi na 13 października 2019 r. Zatem przez cały okres rządów PiS (lata 2015-2019) nie funkcjonował sprawnie proces planowania operacyjnego w państwie.

${ }^{31}$ M. Kozub, Myśleć strategicznie o bezpieczeństwie przyszłości, Warszawa 2013, s. 10.

${ }^{32}$ T. Kęsoń, Bezpieczeństwa jako dyscyplina naukowa w obszarze nauk społecznych, wyzwanie czy powrót do korzeni dla polemologii?, [w:] Bezpieczeństwo - dyscyplina w obszarze nauk społecznych, red. M. Kucharski, Łódź-Warszawa 2012, s. 28.

${ }^{33}$ Jedną z zasadniczych przyczyn tak dużych opóźnień w realizacji zadań planowania obronnego były spory kompetencyjne ówczesnego Ministra Obrony Narodowej, Antoniego Macierewicza, i Prezydenta RP, Andrzeja Dudy, o roli tych dwóch organów w systemie obronności, kierowania państwem w warunkach zewnętrznego zagrożenia bezpieczeństwa państwa i w czasie wojny, sprawowania zwierzchnictwa nas Siłami Zbrojnymi czy też struktury dowodzenia. Minister Obrony Narodowej dążył do zminimalizowania roli prezydenta w systemie obronności państwa i wzrostu znaczenia ministra obrony narodowej. Spory ambicjonalno-kompetencyjne okazały się ważniejsze niż przygotowanie struktur państwa, administracji wszystkich szczebli oraz podmiotów podlegających militaryzacji do skutecznego funkcjonowania i realizowania zadań w warunkach zewnętrznego zagrożenia bezpieczeństwa państwa i w czasie wojny. 
czasie, kiedy miały być zatwierdzone nowo opracowane plany operacyjnego funkcjonowania, Prezes Rady Ministrów wydał zarządzenie nr 137 z dnia 20 września 2019 r. w sprawie Międzyresortowego Zespołu do spraw opracowania Strategii Bezpieczeństwa Narodowego Rzeczypospolitej Polskiej w 2019 r. (M.P. z 2019 r. poz. 904) ${ }^{34}$. W § 11. Zarządzenia zobowiązano Przewodniczącego Zespołu do przedstawienia Radzie Ministrów projektu Strategii Bezpieczeństwa Narodowego Rzeczypospolitej Polskiej w terminie do dnia 31 grudnia 2019 r.

Przebieg procesu planowania obronnego i terminy wydawania poszczególnych dokumentów wskazują na całkowity chaos w zakresie przygotowań obronnych państwa. Należy zadać sobie pytania, kto odpowiada za tak nieskoordynowane działania i czy państwo może sobie pozwolić na tak dalece idącą nonszalancję w zakresie bezpieczeństwa.

Jednym wydanym z 5-miesięcznym opóźnieniem dokumentem (Wytyczne MON) uruchamia się mechanizmy planowania operacyjnego, skracając terminy wykonania planów do 2 miesięcy (w stosunku do wskazanych 9 miesięcy w PSDO). Jednocześnie powołuje się Zespó1 do opracowania projektu nowej Strategii, któremu daje się 2 miesiące na przygotowanie projektu.

Ponadto nie doprowadza się do końca procesu planowania operacyjnego i do grudnia 2019 r. opracowane przez ministrów, centralne organy administracji rządowej, kierowników jednostek organizacyjnych podległych lub nadzorowanych przez Prezesa Rady Ministrów, a także wojewodów plany operacyjne nie zostały przez Prezesa Rady Ministrów zatwierdzone. Nie uruchomiono więc procesów planowania operacyjnego niższego szczebla.

Powinny one być wykonane w terminie 18 miesięcy od wydania PSDO, tj. do 7 lipca 2020 r. ${ }^{35} \mathrm{~W}$ przypadku, kiedy zostanie przyjęta przez Radę Ministrów i zatwierdzona przez Prezydenta RP nowa Strategia Bezpieczeństwa Narodowego RP, cały realizowany w pośpiechu w 2019 r. proces opracowywania planów operacyjnych funkcjonowania administracji w warunkach zewnętrznego zagrożenia bezpieczeństwa państwa i w czasie wojny pójdzie na marne.

Dojdzie do sytuacji, w której plany operacyjne może nawet nie będą zatwierdzone, a już trzeba będzie uruchamiać proces nowego ich opracowywania, bo zmienią się uwarunkowania zapewniania bezpieczeństwa RP, sytuacje planistyczne i zadania, dla których należało będzie opracować nowe plany. Wszystkie natomiast organy niższego szczebla i przedsiębiorcy nie dość, że nie uruchomią procesu planowania, do którego byli zobowiązani na podstawie PSDO z 2018 r., to nie będą mieli aktualnych planów operacyjnych funkcjonowania i militaryzacji, ich plany bowiem odnoszą się do Strategii Bezpieczeństwa Narodowego RP z 2007 r.

\section{Podsumowanie}

Ustanowione aktami prawymi procedury planowania obronnego i planowania cywilnego, a także wydawane wytyczne do opracowywanych dokumentów planistycznych dokładnie wskazują podmioty $\mathrm{i}$ ich powinności w zakresie przygotowania się do realizacji zadań obronnych

\footnotetext{
${ }^{34}$ Zarządzenie ogłoszono 1 października 2019 r. a weszło w życie 9 października 2019 r.

${ }^{35} \mathrm{~W}$ momencie pisania tego artykułu (grudzień 2019 r.) do upływu terminu pozostało 7 miesięcy.
} 
oraz maksymalnie skutecznego reagowania w sytuacjach kryzysowych. Wskazane procedury, terminy realizacji poszczególnych przedsięwzięć w zakresie opracowywania nowych czy też aktualizacji dotychczasowych dokumentów, w przypadku przestrzegania logicznego ich następowania po sobie oraz właściwego zaangażowania $\mathrm{w}$ te procesy zarówno kierownictwa organów, jak i merytorycznych pracowników zatrudnionych na stanowiskach ds. obronnych i zarządzania kryzysowego nie powodują zagrożeń terminowego ich wykonywania.

Jednocześnie możemy wskazać różnego rodzaju obszary, które należałoby przedyskutować i zastanowić się nad ich integrowaniem. Możemy nawet powiedzieć o pewnej nadmiernej dychotomiczności tych działań. Procesy planowania cywilnego będące domeną zarządzania kryzysowego oraz planowania obronnego dotyczące wykonywania zadań w ramach powszechnego obowiązku obrony $w$ niektórych przypadkach są nadmiernie rozłączne, jakkolwiek tworzą swoistość całość. Nie określono m.in. płynnego przechodzenia między sytuacjami kryzysowymi w rozumieniu ustawy o zarządzaniu kryzysowym, a realizacją zadań zawartych w kartach realizacji zadań planów operacyjnych w sytuacjach, kiedy nie wprowadza się rozwiązania szczególnego (w postaci stanu wojennego) a dotyczących zewnętrznego zagrożenia bezpieczeństwa państwa i stanu wojennego. Kolejną nierozwiązaną kwestią są możliwości wykorzystywania rozwiązań zawartych w dokumentach planowania obronnego dotyczących stanowisk kierowania, zapasowych stanowisk kierowania czy też zapasowych miejsc pracy w procesach zarządzania kryzysowego, zwłaszcza w zakresie zagrożeń i zdarzeń o charakterze terrorystycznym (fałszywych i realnych) w sytuacji, gdy wprowadza się poszczególne stopnie alarmowe i zarządza ewakuację pracowników z obiektów stałego funkcjonowania struktur administracji. Na czas ewakuacji traci się ciągłość działania instytucji.

Jednocześnie, jeżeli weźmiemy pod uwagę, że dokumenty tworzone dla potrzeb wykonywania zadań obronnych i zarządzania kryzysowego nie są jedynymi dokumentami planistycznymi wykonywanym często przez te same podmioty, rodzi się konieczność przeanalizowania ich podstaw prawnych i zawartości a następnie wypracowania kryteriów oraz możliwości i zasad ich łączenia w celu zminimalizowania ich liczby. Proces analizy i diagnozy tego stanu rzeczy został zapoczątkowany zarówno w zakresie merytorycznym, jak i legislacyjnym. Szkoła Główna Służby Pożarniczej prowadzi badanie statutowe planów i procesu planowania obronnego i cywilnego w Polsce. Podjęto również działania legislacyjne wynikające $\mathrm{z}$ doświadczeń w zakresie dotychczasowego funkcjonowania systemu zarządzania kryzysowego zwłaszcza w sytuacjach skutków zdarzeń w masowej skali.

Wychodzi temu naprzeciw projekt nowelizacji ustawy o zarządzaniu kryzysowym z 2019 r. Dwa obszary planowania - obronnego i cywilnego, jakkolwiek dotyczyły zapewniania bezpieczeństwa zarówno struktur państwa, jak i obywateli, były wyraźnie rozgraniczane. Naturalną rzeczą jest, że w obliczu różnorodnej przyczynowości powstawania zagrożeń, proces reagowania na zagrożenia musi obejmować kompleksowe pojmowanie bezpieczeństwa i opierać się na nim. Zarówno w podmiotowym i przedmiotowym jego pojmowaniu, jak i w procesach reagowania na zagrożenia pojawiać się będą nowe obszary kryzysów, które 
wymagać będą angażowania - jeśli nie większej liczby, to bardziej różnorodnych sił i środków. Wymuszać to będzie zmiany zarówno w procesie planowania, jak i uruchamiania działań opisanych czy to standardowych procedurach operacyjnych, jak i modułach działania. Tym samym na pierwszy plan wysuwać się będzie nie tyle współistnienie tych dwóch rodzajów planowań, ale ich łączenie przy zachowaniu częściowej odrębności dokumentów opracowywanych dla potrzeb przygotowania państwa do funkcjonowania $\mathrm{w}$ warunkach zewnętrznego zagrożenia bezpieczeństwa państwa i w czasie wojny oraz utrzymania ciągłości działania i reagowania w sytuacjach kryzysowych w ramach zarządzania kryzysowego. Taki kierunek zmian spójny jest z przygotowaną w 2019 r. nowelizacją ustawy o zarządzaniu, która zakłada podział Planu zarządzania kryzysowego na dwie części. W jego skład mają wchodzić (jako część A) Plany ciągłości działania, a część B stanowić mają Plany reagowania kryzysowego.

Nie możemy jednak mówić, że plan ciągłości działania będzie obejmował pokojowe sytuacje kryzysowe oraz przedsięwzięcia realizowane $\mathrm{w}$ procesie podnoszenia gotowości obronnej państwa i wykonywania zadań w warunkach zewnętrznego zagrożenia bezpieczeństwa państwa i wojny. Nie będzie więc on samoistnie zastępował planów operacyjnego funkcjonowania. Takie łączenie procedur planowania obronnego i cywilnego wymagałoby zmiany zarówno ustawy o zarządzaniu kryzysowym, jak i o powszechnym obowiązku obrony Rzeczypospolitej Polskiej i pójścia w procesie legislacyjnym w kierunku opracowania ustawy o bezpieczeństwie narodowym/państwa.

Odrębną kwestią jest rozdźwięk, jaki powstał między regulacjami prawnymi a przestrzeganiem ich zapisów i terminowości oraz przestrzegania procedur cyklu planowania strategicznego. Lata 2015-2019 pokazały, że bezpieczeństwo w zakresie praktycznym planowania stało się nic nieznaczącym frazesem nie tylko w ustach polityków, lecz także organów odpowiedzialnych za przestrzeganie terminów realizacji przedsięwzięć wskazanych w dokumentach wydawanych przez najwyższe organy władzy państwowej. Od 2014 r., tj. przez prawie 5 lat od przyjęcia przez Radę Ministrów projektu Strategii Bezpieczeństwa Narodowego, zatwierdzenia jej przez Prezydenta RP i wydania Polityczno-Strategicznej Dyrektywy Obronnej, nie uruchomiono w państwie procesu planowania obronnego. Wszystkie szczeble władzy administracyjnej i przedsiębiorcy nie opracowali i nie aktualizowali planów operacyjnego funkcjonowania w warunkach zewnętrznego zagrożenia bezpieczeństwa państwa $\mathrm{i}$ w czasie wojny. Ich plany funkcjonowania opierały się na sytuacjach planistycznych wynikających z wypisów z Planu Reagowania Obronnego RP przekazanych im przez Ministra Obrony Narodowej w 2009 r., a odnoszących się do sytuacji międzynarodowej, uwarunkowań i diagnozy bezpieczeństwa, która była podstawą do opracowania i wprowadzenia w życie Strategii Bezpieczeństwa Narodowego RP z 2007 r.

Sytuacji nonszalancji czy też bagatelizowania kwestii bezpieczeństwa nie poprawiła w pełni nawet interpelacja poselska nr 29142 skierowana ponad 2,5 roku po upływie terminów zakończenia procesu planowania obronnego do Prezesa Rady Ministrów przez Pana 
Czesława Mroczka, Posła IX kadencji Sejmu RP (byłego wiceministra obrony narodowej) w styczniu 2019 r. W interpelacji zapytano m.in. o skutek postanowień PolitycznoStrategicznej Dyrektywy Obronnej ${ }^{36}$ w zakresie opracowania Planu Reagowania Obronnego RP, Planów Operacyjnych Funkcjonowania poszczególnych działów administracji rządowej, urzędów centralnych, jednostek organizacyjnych podległych i nadzorowanych przez Prezesa Rady Ministrów i poszczególnych ministrów, wojewodów, Marszałków Województw, powiatów i gmin, Programu Pozamilitarnych Przygotowań Obronnych RP na lata 2017-2023 oraz Programów Pozamilitarnych Przygotowań Obronnych organów administracji poszczególnych szczebli podziału administracyjnego państwa, Programu Rozwoju Sił Zbrojnych na lata 2017-2026. Zgodnie z „§ 2 pkt 2 ww. postanowienia zapisano, że plany oraz inne dokumenty wykonawcze wydane na podstawie Polityczno-Strategicznej Dyrektywy Obronnej Rzeczypospolitej Polskiej z 2009 r., obowiązują do czasu wydania nowych planów i dokumentów wykonawczych według ustaleń przyjętych w nowej dyrektywie, nie dłużej jednak niż 10 miesięcy od daty wejścia w życie postanowienia. Zatem najpóźniej do 6 czerwcu 2016 roku powinny być wydane nowe plany i dokumenty, bowiem poprzednie z tym dniem utraciły swą ważność"37.

W odpowiedzi na interpelację 27 marca 2019 r. sekretarz stanu w Ministerstwie Obrony Narodowej, Wojciech Skurkiewicz, wskazał następujące daty opracowania i przyjęcia dokumentów:

- Program Pozamilitarnych Przygotowań Obronnych Rzeczypospolitej Polskiej w latach 2017-2026 został zatwierdzony przez Prezesa Rady Ministrów w dniu 10.02.2017 r., programy niższych szczebli zostały opracowane;

- Program Rozwoju Sił Zbrojnych Rzeczypospolitej Polskiej w latach 2017-2026 został wprowadzony Zarządzeniem nr 36/MON Ministra Obrony Narodowej z dnia 28 listopada 2018 r.;

- Program Mobilizacji Gospodarki na lata 2017-2026 został przyjęty przez Radę Ministrów przyjęła uchwałą Nr 87/2017 z dnia 13 czerwca 2017 r.

Jednocześnie potwierdził, że proces planowania obronnego $\mathrm{w}$ państwie nie został uruchomiony, ponieważ „w okresie opracowywania nowej edycji dokumentów pozamilitarnego planowania operacyjnego (w II połowie 2015 i I połowie 2016 r.) radykalnej zmianie uległa sytuacja bezpieczeństwa międzynarodowego $\mathrm{w}$ bezpośrednim otoczeniu naszego Państwa, co nie było $\mathrm{w}$ pełni odzwierciedlone $\mathrm{w}$ opracowywanej $\mathrm{w}$ oparciu o wcześniejsze uwarunkowania PSDO RP z lipca 2015 r. Sytuacja ta wymusiła konieczność zmiany obowiązującej PSDO RP. Nowa PSDO RP została przyjęta na mocy postanowienia Prezydenta Rzeczypospolitej Polskiej z dnia 7 stycznia 2019 r. [...] aktualnie prowadzone są

\footnotetext{
${ }^{36}$ Polityczno-Strategiczna Dyrektywa Obronna Rzeczypospolitej Polskiej wprowadzona postanowieniem Prezydenta Rzeczypospolitej Polskiej z dnia 17 lipca 2015 r., weszła w życie 6 sierpnia 2015 r.

${ }^{37}$ Interpelacja nr 29142 Posła Czesława Mroczka do Prezesa Rady Ministrów w sprawie planów obronnych państwa z dnia 26 stycznia 2019 r. http://www.sejm.gov.pl/Sejm8.nsf/interpelacja.xsp?documentId =B577908 DFDA62C8DC1258390004E3B35 (17.12.2019).
} 
prace nad nowym Planem Reagowania Obronnego Rzeczypospolitej Polskiej. Obecnie dokument jest w fazie uzgodnień międzyresortowych"38.

Widzimy więc, że przez prawie 3 lata od „radykalnej zmiany sytuacji bezpieczeństwa międzynarodowego $\mathrm{w}$ bezpośrednim otoczeniu RP" nikogo $\mathrm{z}$ najwyższych władz państwowych problemy nieaktualnych dokumentów reagowania Sił Zbrojnych na zagrożenia i przygotowania instytucji państwa do funkcjonowania $w$ warunkach zewnętrznego zagrożenia bezpieczeństwa państwa nie interesowały, a bezpieczeństwo w ustach polityków staje się jedynie frazesem.

\section{BIBLIOGRAFIA}

Decyzja nr 82/MON z dnia 17 maja 2019 r. w sprawie wprowadzenia do użytku „Wytycznych do planowania operacyjnego i przygotowania przedsiębiorców do funkcjonowania $\mathrm{w}$ warunkach zewnętrznego zagrożenia bezpieczeństwa państwa $\mathrm{i} \backslash$ w czasie wojny" (Dz. Urzęd. MON z 2019 poz. 105).

Interpelacja nr 29142 Posła Czesława Mroczka do Prezesa Rady Ministrów w sprawie planów obronnych państwa z dnia 26 stycznia 2019 r. http://www.sejm.gov.p1/Sejm8. nsf/interpelacja.xsp?documentId=B577908DFDA62C8DC1258390004E3B35.

Kęsoń Tadeusz. 2012. Bezpieczeństwa jako dyscyplina naukowa w obszarze nauk społecznych, wyzwanie czy powrót do korzeni dla polemologii? W Bezpieczeństwo dyscyplina w obszarze nauk społecznych, 28. Łódź-Warszawa. Wyd. Społecznej Akademii Nauk, Studia i Monografie nr 35.

Kęsoń Tadeusz. 2014. Planowanie operacyjne w procesie realizacji zadań obronnych na przykładzie Ministerstwa Pracy i Polityki Społecznej - wybrane problemy. W Projektowanie planowania operacyjnego w administracji publicznej wobec wyzwań i zagrożeń bezpieczeństwa narodowego, 135. Warszawa. Wyd. Kancelaria Prezesa Rady Ministrów.

Kęsoń Tadeusz. 2014. Zarządzanie kryzysowe w Polsce. W Zarządzanie kryzysowe elementem bezpieczeństwa narodowego Rzeczypospolitej Polskiej - praca zbiorowa, 79-80. Naukowe Wydawnictwo Piotrkowskie, Filia Uniwersytetu Jana Kochanowskiego w Piotrkowie Trybunalskim.

Kozub Marian. 2013. Myśleć strategiczni o bezpieczeństwie przyszłości. Warszawa: Wyd. AON. Odpowiedź sekretarza stanu w Ministerstwie Obrony Narodowej Wojciecha Skurkiewicza z dnia 27 marca 2019 r. na interpelację nr 29142 w sprawie planów obronnych państwa http://www.sejm.gov.pl/sejm8.nsf/InterpelacjaTresc.xsp?key=BAQJ M9\&view=1 .

Onyszkiewicz Janusz. 1998. Rola Planowania Polityki Obronnej. W Seminar The Role of Defence Policy Planning, 10 i 162. Warszawa. Wyd. MON Departament Bezpieczeństwa Międzynarodowego.

Postanowienie Prezydenta Rzeczypospolitej Polskiej z dnia 12 marca 2004 r. o wydaniu Polityczno-Strategicznej Dyrektywy Obronnej (M.P. Nr 16, poz. 225).

\footnotetext{
${ }^{38}$ Odpowiedź sekretarza stanu w Ministerstwie Obrony Narodowej Wojciecha Skurkiewicza z dnia 27 marca 2019 r. na interpelację nr 29142 w sprawie planów obronnych państwa http://www.sejm.gov.pl/sejm8.nsf/ Interpelacja Tresc.xsp?key=BAQJM9\&view=1 (17.12.2019).
} 
Postanowienie Prezydenta Rzeczypospolitej Polskiej z dnia 16 lipca 2009 r. o wydaniu Polityczno-Strategicznej Dyrektywy Obronnej (M.P. Nr 48, poz. 705).

Postanowienie Prezydenta Rzeczypospolitej Polskiej z dnia 17 lipca 2015 r. o wydaniu Polityczno-Strategicznej Dyrektywy Obronnej (M.P. poz. 697).

Postanowienie Prezydenta Rzeczypospolitej Polskiej z dnia 29 grudnia 2018 r. w sprawie Polityczno-Strategicznej Dyrektywy Obronnej (M.P. z 2019 r. poz. 15).

Rosa Bogdan, Zalewski Andrzej. 2006. „Militaryzacja”. Wiedza Obronna, Kwartalnik Towarzystwa Wiedzy Obronnej, Rok XXXIII, Nr 3/218: 91-114.

Rozporządzenie Rady Ministrów z 3 listopada 2015 r. wsprawie wykazu przedsiębiorców o szczególnym znaczeniu gospodarczo-obronnym (Dz. U. poz. 1871 z późn. zm.).

Rozporządzenie Rady Ministrów z dnia 16 grudnia 2016 r. zmieniające rozporządzenie w sprawie obiektów szczególnie ważnych dla bezpieczeństwa i obronności państwa oraz ich szczególnej ochrony (Dz. U. z 2017 r. poz. 42).

Rozporządzenie Rady Ministrów z dnia 21 września 2004 r. w sprawie reklamowania od obowiązku pełnienia czynnej służby wojskowej w razie ogłoszenia mobilizacji i w czasie wojny (Dz. U. Nr 210, poz 2136 z poźn. zm.).

Rozporządzenie Rady Ministrów z dnia 24 czerwca 2013 r. w sprawie obiektów szczególnie ważnych dla bezpieczeństwa i obronności państwa oraz ich szczególnej ochrony (Dz. U. Nr 166, poz. 1090 z późn. zm.).

Rozporządzenie Rady Ministrów z dnia 24 listopada 2009 r. w sprawie militaryzacji jednostek organizacyjnych wykonujących zadania na rzecz obronności lub bezpieczeństwa państwa (Dz. U. nr 210, poz. 1612).

Rozporządzenie Rady Ministrów z dnia 27 kwietnia 2004 r. w sprawie przygotowania systemu kierowania przygotowania systemu kierowania bezpieczeństwem narodowym (Dz. U. Nr 98, poz. 978).

Rozporządzenie Rady Ministrów z dnia 3 sierpnia 2004 r. w sprawie przygotowania i wykorzystania systemów łączności na potrzeby obronne państwa (Dz. U. Nr 180, poz. 1855).

Simon Jeffrey. 1998. Changing National Security Concept and Defence and Military Doctrines in Central and Eastern Europe. W Seminar The Role of Defence Policy Planning, 17 i 169. Warszawa Wyd. MON Departament Bezpieczeństwa Międzynarodowego.

Ustawa z dnia 17 lipca 2009 r. o zmianie ustawy o zarządzaniu kryzysowym (Dz.U. Nr 131, poz. 1076).

Ustawa z dnia 21 czerwca 2002 r. o stanie wyjątkowym (Dz. U. z 2017 r. poz. 1928 - tekst jednolity).

Ustawa z dnia 26 kwietnia 2007 r. o zarządzaniu kryzysowym (Dz. U. Nr 89, poz. 590).

Ustawa z dnia 29 października 2010 r. o rezerwach strategicznych (Dz. U. z 2017 r. poz. 1846).

Ustawa z dnia 29 sierpnia 2002 r. o stanie wojennym oraz o kompetencjach Naczelnego Dowódcy Sił Zbrojnych i zasadach jego podległości konstytucyjnym organom Rzeczypospolitej Polskiej (Dz. U. z 2017 r. poz. 1932 - tekst jednolity). 
Wyrok Trybunału Konstytucyjnego z dnia 21 kwietnia 2009 r. Sygnatura akt: 50/07 (Dz.U. z 2009 r. Nr 65, poz. 533).

Zarządzenie nr 137 Prezesa Rady Ministrów z dnia 20 września 2019 r. w sprawie Międzyresortowego Zespołu do spraw Opracowania Strategii Bezpieczeństwa Narodowego Rzeczypospolitej Polskiej (M.P. z 2019 r. poz. 904). 